\title{
Personalized medicine: new genomics, old lessons
}

\author{
Kenneth Offit
}

Received: 10 February 2011/ Accepted: 30 May 2011/Published online: 26 June 2011

(C) The Author(s) 2011. This article is published with open access at Springerlink.com

\begin{abstract}
Personalized medicine uses traditional, as well as emerging concepts of the genetic and environmental basis of disease to individualize prevention, diagnosis and treatment. Personalized genomics plays a vital, but not exclusive role in this evolving model of personalized medicine. The distinctions between genetic and genomic medicine are more quantitative than qualitative. Personalized genomics builds on principles established by the integration of genetics into medical practice. Principles shared by genetic and genomic aspects of medicine, include the use of variants as markers for diagnosis, prognosis, prevention, as well as targets for treatment, the use of clinically validated variants that may not be functionally characterized, the segregation of these variants in non-Mendelian as well as Mendelian patterns, the role of gene-environment interactions, the dependence on evidence for clinical utility, the critical translational role of behavioral science, and common ethical considerations. During the current period of transition from investigation to practice, consumers should be protected from harms of premature translation of research findings, while encouraging the innovative and cost-effective application of those genomic discoveries that improve personalized medical care.
\end{abstract}

\section{Introduction}

Personalized medicine did not begin in the post-genome era. One colleague, trained before Watson and Crick's

\section{K. Offit ( $\square)$}

Clinical Genetics Service, Department of Medicine, Program in Cancer Biology and Genetics, Sloan-Kettering Institute, Memorial Sloan-Kettering Cancer Center, New York, NY 10021, USA

e-mail: offitk@mskcc.org landmark discovery, asked if she had been practicing "impersonal medicine" all those years. As one historian has put it: "The new language of genomics, as applied to medicine, is less a revolution than an evolution" (Steele 2009). The current enthusiasm, and occasional "hype," about personalized genomics follows several decades of scientific discovery and clinical translation in human genetics. Rather then constituting a new paradigm, personalized genomics is best viewed as incremental to the model built over several decades of the practice of genetic medicine. In this Perspectives, we will focus on the lessons learned from genetic medicine, which provide a solid foundation to define the scientific and clinical challenges inherent in the application of genomics to personalized medicine.

\section{The relationship of genomics and personalized medicine}

There has long been interest in personalizing medicine. Hippocrates individualized diagnosis and treatment, for example, by giving cold food to a "phlegmatic" person (Steele 2009). Today, personalized medicine, informed by a molecular understanding of disease, has brought new classification systems as well as more effective preventive and therapeutic interventions. Personalized medicine is "a form of medicine that uses information about a person's genes, proteins, and environment to prevent, diagnose, and treat disease" (National Cancer Institute 2011). Thus, a physician-even a pre-genomics trained general practitioner-can deliver personalized care in the absence of DNA profiles. This distinction is often garbled. For example, in the version of H.R. 5440 (re-introduced in the last Congress and originally introduced by then-Senator Obama) personalized medicine is defined as "any clinical 
practice model that emphasizes the systematic use of preventive, diagnostic, and therapeutic interventions that use genome and family history information to improve health outcome" (H.R. 5440, 2010). Such a definition of personalized medicine, while politically correct, incorrectly omits vital non-genetic components including environmental or occupational exposures.

Another semantic distinction, with enormous regulatory, ethical, and practical implications, grows from our assumption that personalized genomics must meet the same standards as other components of personalized medicine. Some commercial entities sought to define a non-medical role of personal genomics as a "recreational" or "information-seeking" pursuit. In December 2008, a multidisciplinary work shop was convened by the National Institutes of Health and the Centers for Disease Control to review the scientific foundation for using personalized genomics as a component in personalized medicine. The attendees included investigators in human genetics and genetic epidemiologic research, leadership at NIH and CDC, as well as the senior leaders of the for-profit "direct-to-consumer" (DTC) genomic profiling companies (Khoury et al. 2009). At one point in the public session of that meeting, I had the opportunity to ask the panel of corporate leaders if they intended genomic profiles ultimately to be reimbursed by third party carriers as part the personalized medical management of individuals. At that time, not that long ago, the unanimous answer of the CEO's was that their personalized genomics "spit kits" were definitely not medical tests and "medicalization" was not part of their business model. However, in the past year, spurred by a sharply critical House Committee on Energy and Commerce Subcommittee on Oversight and Investigations report on DTC marketing of personalized genomics, as well as open hearings and device notification letters sent by the FDA (Vorhaus 2010), the mission and marketing strategy of several forprofit genomics profiling providers underwent post-transcriptional modification. Working with laboratories that are CLIA approved, some companies began seeking a role as providers of pre-symptomatic or diagnostic medical tests. While other articles in this volume explore the broad issues of DTC marketing of genomic profiling, our focus here is on the scientific foundation of genomic research and personalized medicine. In this discussion, we will assume that personalized genomics plays a vital, but not exclusive role in an evolving model of personalized medicine.

\section{The scope of scientific challenges facing the use of personalized genomics in medicine}

The scientific foundation for personalized genomics draws on a range of disciplines including, among others, basic genetics, population genetics, genetic and clinical epidemiology, behavioral science, and emerging regulatory science. The applications of genetics and genomics in personalized medicine have included elements of risk assessment, diagnosis, prognosis, and treatment (Table 1). The path from concept to clinical use in each of these domains involves basic, translational, and regulatory science (Hamburg and Collins 2010). The fusion of personal genomics and medicine is informed by reference to the model of four phases of scientific research leading from discovery to improved health outcomes. The first phase (T1) includes discovery and replication of findings, the second (T2) evaluates new tests for validity and utility, the third phase (T3) evaluates best approaches for diffusion and dissemination of tests, and the final phase of translation from bench to bedside (T4) involves research addressing population impact, effectiveness, and economic aspects (Khoury et al. 2007). Across these four phases, research studies evaluate personalized genomics using the "ACCE" framework: analytic validity, clinical validity, clinical utility, and ethical, legal, and social implications (Haddow and Palomaki 2004). This scientific framework encompasses but does not emphasize the notion of "personal utility" of medical tests, which, we will shortly argue, is not a unique feature of "spit test" genomics, but has been a part of medical practice for decades.

\section{The lessons of "personalized genetics" relevant to "personalized genomics"}

The venerable field of genetics refers to the study of single genes, while the emerging field of genomics refers to the study of all of a person's genes (Guttmacher and Collins 2002; National Human Genome Research Institute 2010). Distinguished laboratory scientists increasingly speak about the new promise of knowledge of one's "personal genome," predicting a time when genomics will provide warnings and inform preventive actions. Scholars debate whether we are still waiting for the genomics revolution, and if its role in personalized medicine has been overblown (Marshall 2011). Of course, the reality is that many clinicians have been using genetics to personalize practice for decades. As will be argued here, the distinctions between genetics and genomic medicine are more quantitative than qualitative. The traditional dogma is that genetic and genomic medicine are qualitatively different for a variety of reasons including the non-directive nature of genetic counseling for single gene disorders, the use of genetic information for diagnosis in contrast to the use of genomic information (including somatic changes in cancers) as complex biomarkers of risk and outcome, and the interplay of 
Table 1 Examples of genetic and genomic testing in personalized medicine

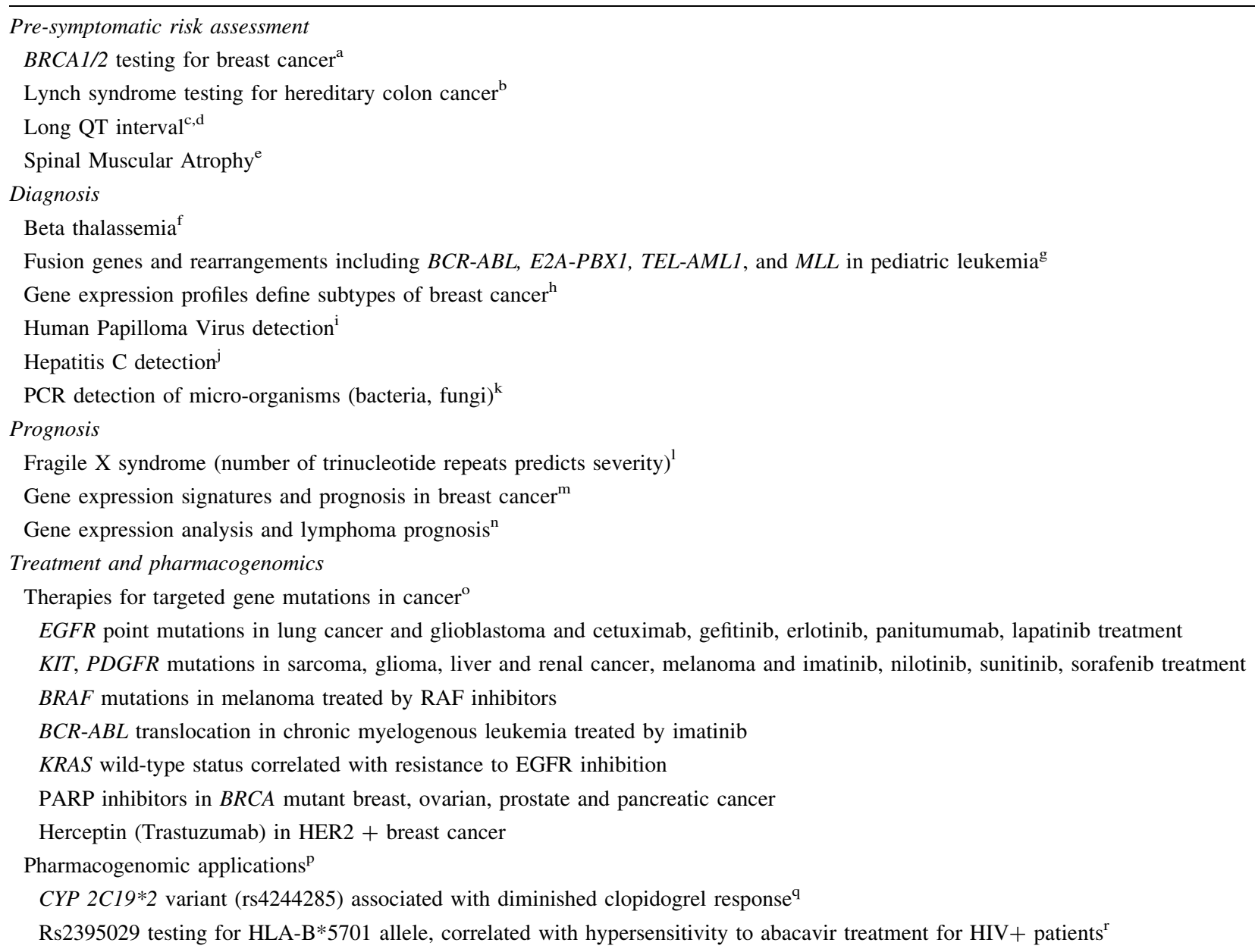

${ }^{\mathrm{a}}$ Robson and Offit (2007), ${ }^{\mathrm{b}}$ EGAPP (2009a), ${ }^{\mathrm{c}}$ Napolitano et al. (2005), ${ }^{\mathrm{d}}$ Lehnart et al. (2007), ${ }^{\mathrm{e}}$ Prior et al. (2008), ${ }^{\mathrm{f}}$ Galanello and Origa (2010), ${ }^{\mathrm{g}}$ Carroll et al. (2003), ${ }^{\mathrm{h}}$ Sorlie et al. (2001), ${ }^{\mathrm{i}}$ Nicol et al. (2010), ${ }^{\mathrm{j}}$ Pham et al. (2010), ${ }^{\mathrm{k}}$ Tsalik et al. (2010), ${ }^{\mathrm{l}}$ Sherman et al. (2005), ${ }^{\mathrm{m}}$ Kim and Paik (2010), ${ }^{\mathrm{n}}$ Rosenwald et al. (2002), ${ }^{\mathrm{o}}$ Macconaill and Garraway (2010), ${ }^{\mathrm{p}}$ U.S. Food and Drug Administration (2011), ${ }^{\mathrm{q}}$ Shuldiner et al. (2009), ${ }^{\mathrm{r}}$ Colombo et al. (2008)

genomics and environmental and epigenetic variables (Guttmacher and Collins 2002; Khoury 2003). As will be argued here, virtually all of these "unique" features of genomics in medicine were presaged and have been incorporated into the translation of genetics to medicine. Over the past decade, the clinical translation of genetics went beyond the largely pediatric and reproductive emphasis of medical genetics, and became part of the core practice of a many fields of medicine, most notably cancer prevention and management (Offit 1998). While the computational challenges of genomics are especially daunting, the translation of genomics to the clinic derives squarely from genetics practice. Indeed, single or multiplexed genetic profiles, have been applied to pre-symptomatic risk assessment, as well as to diagnostic, prognostic, and therapeutic application in several fields, including cancer care. Genetic profiling in personalized medicine is now de rigueur in many medical disciplines where it has shifted traditional paradigms (Green and Guyer 2011). In oncology, the use of pre-symptomatic genetic testing and "targeted therapies" tailored to genetic profiles of tumors is part of recommended evaluation for cancers of the colon, lung, breast and other sites (American Society of Clinical Oncology 1996, 2003, 2010; Robson and Offit 2007; Macconaill and Garraway 2010; McDermott et al. 2011). It is therefore instructive to review some of the insights gleaned from the recent period of scientific discovery and translation to practice of genetic medicine, since the lessons learned are directly relevant to the challenges facing personalized genomics. 
Clinical translation of genetic markers can take place even in the absence of a complete understanding of their functional biologic significance

The use of linkage or "reverse genetics" led to discoveries of the basis of single gene disorders, such as hemophilia, cystic fibrosis, and breast cancer (reviewed in Botstein and Risch 2003). In the case of BRCA1, over 15 years after its discovery, its myriad cellular roles continue to be defined (Boulton 2006), complicating prediction of the functional (hence clinical) significance of missense variants routinely detected (Spearman et al. 2008). The same limitation applies for the estimated 50,000-200,000 single nucleotide polymorphisms (SNPs), which may contribute to disease (Orr and Chanock 2008). Non-synonymous SNPs in exons are the most amenable to estimation of their functional significance, however, even synonymous SNPs can effect mRNA stability and alter splicing signals, and have been linked to diseases such as androgen-insensitivity syndrome and thrombasthenia (Chamary et al. 2006). SNPs in introns and regulatory regions, and SNPs in "gene deserts" may affect gene regulation, as in the case of prothrombin disorders, schizophrenia, or colon cancer (Poort et al. 1996; Law et al. 2006; Pomerantz et al. 2009). Recognizing that most SNPs are merely "markers" of a genetic lesion, and that frequencies of disease-associated SNPs may be obscured or falsely elevated as a result of population heterogeneity, the lack of a precise biological understanding of genetic or genomic associations limits but does not preclude their clinical application. In the mid 1990s, we and others counseled families regarding prophylactic mastectomies based only on markers linked to the BRCA1 locus. Today, we and others will soon offer testing for risk modifying variants affecting BRCA2 penetrance and expressivity (Gaudet et al. 2010; Antoniou et al. 2010), even in the absence of knowledge of their function. The proof of clinical utility of genetic or genomic predictive markers does not depend on a complete biological functional understanding of the genetic variant in question, although such an understanding remains critical for pharmacologic targeting.

\section{Human disease susceptibility is the result of rare genetic variants of high penetrance as well as common genomic variants of low penetrance}

After more than a decade of debate between the Common Disease, Common Variant (CDCV) and Common Disease Rare Variant (CDRV) camps, it is now evident that both sides have won. This debate is reminiscent of a similar dispute, a century earlier, between the "Mendelians" and the "Biometricians," ultimately settled by RA Fisher who established that multiple genes in additive fashion-and following Mendel's laws-could account for continuous variation of phenotypic expression (Provine 2001). With the completion of dozens of genome wide association studies, it is now clear that the bulk of excess familial risk of many diseases is not accounted for by common variants, the so called "missing heritability" of human disease (Maher 2008). This is not to diminish the biological insights made by the GWAS studies, which have elucidated hidden pathways of important etiologic significance. For example, GWAS studies identified the complement pathway in agerelated macular degeneration and autophagy pathways in Crohn's disease, as well as a number of pathways not evident from the somatic genetics of cancer (Carvajal-Carmona 2010; Stadler et al. 2010). Most in the field have come to appreciate that both the common and rare variant hypotheses have contributed significantly to our understanding of human disease susceptibility (Schork et al. 2009). Nonetheless, the search continues for the missing heritability of disease, focusing on gene-environment interactions, germline copy number variants, epigenetic and epistatic events, and, most recently, rare variants missed by prior GWAS and linkage approaches but resolvable using next generation sequencing technologies (NGS). The current interest in NGS approaches to discover rare variants, successful thus far in uncovering rare variants associated with recessive syndromes, has proven more challenging for autosomal dominant syndromes, for example, adult-onset cancer families wild-type for known predisposition genes. The lesson being learned in this process, consistent with the overall theme of "new genomics, old lessons," is that unraveling the personalized genome through NGS often relies on traditional genetic approaches. The tens of thousands of coding variants discovered by the average exome scan may be reduced by an order of magnitude by co-segregation of the variant in an affected kindred. The proof of association of these genomic variants will rely on causal evidence of functional significance of the genetic mutations observed. Similarly, the proof of "actionability" of genomic variants at the clinical level will largely rely on empiric approaches established in the era of single gene discovery, validation, and clinical translation.

\section{Genetic and genomic variants may manifest phenotypically in non-Mendelian patterns}

Another lesson learned from the "personalized genetics" era that should inform the translation of genomics to practice stems from observations of non-Mendelian patterns of inheritance of susceptibility to complex human traits. Such phenomena as imprinting, de novo germline mutations, and epigenetic mechanisms of inheritance are still being defined as they apply to the transmission genetics of single gene disorders. While the de novo 
mutation rates for some traits such as neurofibromatosis and hereditary endocrine tumors are $30-50 \%$ (Garber and Offit 2005), the de novo mutation rates for the most frequent susceptibilities to cancers of the breast and colon remain unclear. De novo germline copy number variation as a mechanism of susceptibility to autism, reviewed in this issue, was a hallmark early discovery of the genomics era (Sebat et al. 2007), and de novo point mutations have recently been observed in individuals affected by mental retardation (Vissers et al. 2010). Studies of de novo genomic variation have not yet been performed for many complex human traits. Non-Mendelian patterns of transmission of epigenetic silencing of genes associated with colon cancer (e.g. $M L H 1$ ), can create a conundrum for genetic counseling due to the observation that epimutation of the promoter of this gene may vary from one generation to the next (Hitchins 2010). Mechanisms of epigenetic silencing of shared promoters of adjacent genes (e.g. MSH2, PTEN/KILLIN) are still being described (Hitchins 2010; Bennett et al. 2010). Phenomena such as promoter methylation in the germline, not detected on first generation genome scans, will need to be taken into consideration as personalized genomic profiles evolve.

\section{The genomic model of human disease, like}

the multifactorial genetic model, will incorporate environmental as well as genetic modifiers

The genetics era produced important insights into the interaction of genetic and environmental factors, for example the metabolism of carcinogens mediated by xenobiotic genes (Shields and Harris 2000), as well as the first models of pharmacogenetic variants of drug metabolism (Katz and Bhathena 2009). A challenge in the transition from genetics to genomics is the complexity of information; genomic variants may play etiologic roles for a spectrum of diseases, and interact with other variants and environmental factors (Conti et al. 2010). Computational models will need to be developed to determine how polygenes and environmental factors interact to perturb cellular regulatory networks, affecting cellular phenotypes and determining a rationale for targeted prevention of disease (Schadt et al. 2009).

\section{Analytic validity of genotyping cannot be taken for granted}

Hard lessons were learned during the "personalized genetics" era about the critical translation of genotyping from the research laboratory to the clinic (T2 phase of "laboratory science") (Khoury et al. 2009). Catastrophic results may follow an analytic failure of a single genotype. In one such case, a miscall of a $B R C A$ mutation led to an unnecessary surgery and legal action by the patient against the testing laboratory (Peres 1999). At our institution, where the internal clinical lab repeated all positive (and true negative) genotyping results before risk reducing surgeries were recommended, both analytic and post-analytic errors by external academic and commercial laboratories were noted in the years following the initial description of the BRCA genes. In the genomics era, similar reporting inconsistencies have also been observed. Several individuals were sent widely divergent results when the same sample was tested in different commercial laboratories, indicating suspected analytic or post-analytic error (Fleming 2008; Davies 2008; Ng et al. 2009).

Encouraged by calls from professional societies (e.g. ASCO 2010), and as required by law in some states such as New York, the same quality assurance standards required for clinical genetic tests are being requested of genomic "profiles" (Vorhaus 2010; Hamburg and Collins 2010). It is now evident that the "T2" phase of clinical laboratory science will not be overlooked in the incorporation of genomics to personalized medicine.

\section{Behavioral science is needed to inform the translation of genetics (and genomics) to preventive practice, in order to maximize benefit and to avoid the consequences of incomplete risk communication}

One of the most important lessons of the "personalized genetics" era, emerging largely from NHGRI supported research, is that even an analytically and clinically validated genetic test may fail as a tool for prevention or screening unless it is translated to a behavioral action by the at-risk individual. A large part of the art as well as practice of genetic counseling is built on a foundation of behavioral research. A goal of applied research in this area has been to minimize the adverse impact of testing, and promote the uptake of recommended primary or secondary preventive interventions following testing (Heshka et al. 2008). Initial reports of self-administered genomic "profiling" confirm that compliance with such interventions as a lower fat diet and exercise were positively impacted by sharing results with a physicians (Bloss et al. 2011). Researchers and practitioners during the era of personalized genetics also discovered that the diffusion of genetic information in families may be highly variable. Families may be dysfunctional; not every individual wants to know genetic information, or wants their relatives to know. Such conflicts can enmesh the genetics practitioner or researcher in the liability trap of the so-called "duty to warn" at-risk relatives (Offit et al. 2004). 
The individual response to probabilistic genetic information varies and depends on context

There is variation both within families and between individuals regarding the processing of probabilistic risk information, and ability to act on it. For example, Craig Venter pointed out: “...We have, in truth, learned nothing from the genome other than probabilities. How does a 1 or 3 percent increased risk for something translate into the clinic? It is useless information" (Spiegel 2010). From the experience of genetic counseling, we have learned that perceived utility of probabilistic information can depend on the context of presentation. For example, does the $3 \%$ increase in risk referred to above pertain to absolute or relative risk? A $3 \%$ increase in absolute risk of pancreatic cancer, observed in BRCA2 mutation carriers, from 1 to $4 \%$, is quite significant, while a $3 \%$ increase in relative risk for pancreatic cancer due to a common SNP (relative risk 1.03 compared to 1.0) indeed seems negligible. For cancer at least, not all SNPs have negligible relative risks (Stadler et al. 2010). For example for both testicular cancer and myeloproliferative disease the increased risks are on the order of two to threefold (Stadler et al. 2010). In addition, while risks are generally quoted for the common heterozygote, the risks for the rare homozygote may be higher; in addition epidemiologic concepts of attributable risk are often misleadingly applied in genomics (Offit 2009). Finally, research has shown that psychosocial context is important for translation of genetic (and genomic) risk information (Heshka et al. 2008).

\section{Genetic or genomic markers with proven analytic and clinical validity and a strong biological rationale may not meet evidence-based standards of clinical utility}

Over the past two decades clinical investigators have established an evidence base for the utility of genetic tests in a variety of medical contexts. The same will apply to genomic tests. In the area of breast and colon cancer genetics, for example, the clinical utility of genetic testing has been documented (Evaluation of Genomic Applications in Practice and Prevention 2009a, b; Domchek et al. 2010). Numerous professional organizations have conducted evidence reviews, and at the federal level, the need to produce evidence-based recommendations on validity and utility of genomic applications in medicine was recognized by the creation of the Evaluation of Genomic Applications in Practice and Prevention (EGAPP) working group (Teutsch et al. 2009). The EGAPP working group adapted the methods of the US Preventive Services Task Force (USPSTF). It is important to note that these and other groups' evidence-based evaluations did not all reach anticipated conclusions. Of the ten comprehensive reviews carried out or in preparation by EGAPP, all but one have been unfavorable or neutral (Marshall 2011); several of these reports have yet to be published. For example, there was mixed evidence regarding the association between CYP450 genotypes and selective serotonin uptake inhibitor (SSRI) metabolism, efficacy, and tolerability in the treatment of depression (Evans and Khoury 2007; Agency for Healthcare Research and Quality 2007), and insufficient evidence of clinical utility of UGT1Al genotyping to predict toxicity of irinotecan therapy (Evaluation of Genomic Applications in Practice and Prevention 2009b). In evaluating the clinical utility of Factor V Leiden $(F V L)$ testing alone, or in combination with prothrombin G20210A analysis, there was no direct evidence found to support testing for these mutations leading to improved clinical outcomes in adults with a history of venous thromboembolism or their adult family members (Evaluation of Genomic Applications in Practice and Prevention 2011). Similarly, pharmacogenomic testing to guide warfarin therapy, added to the product label in 2007 by the FDA, was not approved for Medicare reimbursement in mid2010; large trials to establish the evidence for this example of pharmacogenetics are still in progress (Klein et al. 2009; Conti et al. 2010; Meckley et al. 2010). Despite considerable enthusiasm and a very strong biologic rationale, recent results from two large randomized trials surprisingly failed to support the clinical utility of CYP2D6 testing accompanying tamoxifen treatment of women with breast cancer (Rae et al. 2010; Leyland-Jones et al. 2010). These findings underscore the critical importance of an evidence base to inform the incorporation of genomics into the practice of medicine, and the potential dangers of self administration of these tests without expert interpretation. The application of traditional evidentiary standards to genomics also may stir debate. For example, it appears that funding for the EGAPP program itself will be seriously diminished in the near future (Marshall 2011). Such developments are particularly difficult at a time when the scientific context for the evaluation of the clinical utility of personalized genomics is comparative effectiveness research, wherein the additive role of genomics is measured compared to existing medical practices (Wilensky 2006).

\section{The promise of personalized, genomic medicine should be informed by the past decade of experience developing genetically targeted therapies}

In the era of genetically targeted agents, the cost for development of "biological" therapies is fast approaching the $\$ 1.2$ billion cost per drug for conventional pharmaceutical development (Malik and Khan 2010). At the same time, large pharmaceutical companies have come to view 
genetically targeted therapy as a two-edged economic sword. While genomic targeting may identify the proportion of non-responding patients who cause up to $50 \%$ of new drugs to fail phase III trials, it will also narrow the target population, decreasing the potential for "blockbuster" drugs. For example, when KRAS genotyping of colon tumors was shown to correlate with resistance to pharmacologic inhibition of EGFR, the indicated uses for those drugs diminished. An emerging concern in the genomics era is that some targeted drugs for "orphan diseases" (e.g. PARP inhibitors for BRCA mutant tumors) may not meet profitability thresholds set by pharmaceutical companies, or may be marketed for more broadly defined phenotypes where efficacy is more uncertain. While it is true that personalized genomics may improve treatment efficacy and decrease toxicity, a lesson of the genetics era is that the economic hurdles of the biological drug development pipeline remain significant (Malik and Khan 2010).

\section{Concepts such as "personal utility" and non-traditional modes of delivery of risk information are not new to personalized genomics}

Both genetic and genomic tests may be provided within or outside the realm of health care providers, and both may be deemed to be of value to the individual even if there is no available medical intervention. Distinctions need to be made between DTC marketing of genetic tests with referral to health care professionals, and DTC provision of these services circumventing the health care system (American Society of Clinical Oncology 2010). There is emerging experience with provision of genetic counseling augmented by telemedicine and virtual interactions with health care professionals (Zilliacus et al. 2010). The explicit bypassing of health professionals in the provision of genetic and genomic information of uncertain validity and utility raises risks of false reassurance or false alarm, and consequent adverse psychological sequelae (Offit 2008). Several decades of genetic counseling have resulted in the conclusions by meta-analyses of remarkably few adverse psychological sequelae (Braithwaite et al. 2004; Heshka et al. 2008) following counselor-informed genetic testing. A recent study of 2,037 individuals who selfadministered DTC genomic risk profiling with no formal role of genetics professionals found a correlation in testrelated distress with lifetime risk (Bloss et al. 2011). Of note, 57 individuals in this series $(2.7 \%)$ experienced severe (clinically significant) test-related distress by psychometric scales. In the era of genomics, as in genetics, even one strongly adverse reaction resulting in harm to the individual can have profound psychological or even legal consequences.
An implied precept of clinical genetics has been the notion that "personal utility" of a genetic test hinges on an assumption of clinical validity and utility. Implicit in modern medical practice is the principle that personal utility may be derived from knowledge of the risk or diagnosis of untreatable disorders, such as Huntington disease (Wiggins et al. 1992) or Li Fraumeni syndrome (Lammens et al. 2010). Recent findings regarding testing for Alzheimer disease confirm those prior findings; genetic testing of such individuals can be performed without immediate adverse sequelae (Green et al. 2009). However, tests of unknown clinical validity or clinical utility would logically be unsuited to result in "personal utility," unless the perceived utility was based on a misunderstanding of the meaning of the test. In an instructive case, the first individual to have his genome sequence publically disseminated, admitted that he initially misinterpreted the clinical and personal utility of a non-synonymous variant of unknown significance in his BRCAl gene, until he consulted a specialist (Watson 2009). Studies of "personal utility" of validated genetic tests were performed at the outset of the genetics revolution; this research concluded that an indeterminate test result for a lethal disease can have the most severe sequelae (Wiggins et al. 1992). This is a lesson especially relevant in the "genomic" era, since, at the present time most, if not all of the common variants for common diseases are, for the most part, not clinically actionable (Evaluation of Genomic Applications in Practice and Prevention 2010; Wellcome Trust Case Control Consortium 2007; Stadler et al. 2010; Manolio 2010). Epistatic interactions between these variants as well as interactions with environmental factors are not yet known, further limiting the immediate prospects for personal utility of self-administered genomic profiles.

As was the case for genetic counseling for complex disorders, new models for "genomic counseling" are most responsibly offered first in a research and then a clinical context

The description of the efforts to deduce potentially pathogenic mutations from the genome of a single 40-year-old male (Ashley et al. 2010) supports the rationale for imbedding these efforts in a research context. The reasons for caution revealed in that study include: limitations of current sequencing platforms (e.g. failure to detect structural genomic changes or to distinguish mutations on the same or different chromosomes), the absence of a central repository of rare and disease-causing variants, and the need for longitudinal follow-up to update counseling based on new information (Ormond et al. 2010). The clinical translation of the estimated 50-100 variants implicated in inherited disorders, and present in a 
"personal genome" (The Thousand Genomes Consortium 2010) will require improved human reference sequence quality, variation, and annotation, which at present require extensive manual analysis and orthogonal validation of variants to derive clinical meaning from the data (Mardis 2010). Current clinical models and training do not readily allow for the timely communication of such a volume of genetic information to individuals (Ormond et al. 2010). While unraveling of the genomes of a dozen cancer types has led to the discovery of several new oncogenes and tumor suppressor genes (e.g. IDH1 mutations in leukemia and glioblastoma, DPP10 deletions in mesothelioma, novel translocations in prostate cancer), the translation of these findings to personalized therapeutics also remains a research-in-progress (Weinberg 2010). The interpretation, counseling, and medical implications resulting from analysis of individual germline or cancer-derived genome sequences will likely entail higher human costs and liabilities than costs to generate the genotypes (Mardis 2010).

As these data on rare germline and somatic variants continues to accumulate, the path for clinical validation will be built using a multidisciplinary approach to genomic counseling. The spectrum of evidentiary standards required for personalized medicine is illustrated by two panels tasked to review personalized genomic data in different research and clinical contexts. For the EGAPP Working Group, the criteria for clinical utility of testing were the "high bar" established by evidence-based reviews. The reviews of a single or panels of genetic variants took a year or more to complete, and often failed to document evidence of clinical utility (Evaluation of Genomic Applications in Practice and Prevention 2009a, b, 2010, 2011; Evans and Khoury 2007). However, for a study using a panel of SNPs to assess the impact of personalized genomics on 4,372 individuals, the scientific advisory board was tasked with evaluating clinical validity of the SNP and if the SNP was potentially actionable (Keller et al. 2010). In just a few meetings, 17 SNPs were approved (2 not approved) for inclusion. Because genomic profiling was being offered in the context of a longitudinal research study, the ethical and scientific conduct of the study allowed for communication of genomic markers of unproven clinical utility. Such an investigational path for the translation of personalized genomics resembles that proposed in the early days of $B R C A$ analysis, when testing was encouraged in the context of longitudinal research studies (American Society of Clinical Oncology 1996). It is also consistent with current emerging consensus in the bioethical community that the issue is no longer if genomic information should be returned to consenting individuals in the context of research, but how to do this while avoiding harm (Bredenoord et al. 2011).
The same range of ethical issues apply to "personalized genomics" as to personalized genetics

The era of personalized genetics brought with it a focus on ethical implications of research and the process of informed consent. For example, the informed consent for genetic testing for cancer includes 14 elements (American Society of Clinical Oncology 2010). These same elements, relating to potential risks and benefits, are relevant to genomic testing and research. In addition, a move toward transparency of disclosure now requires scientists, physicians, and genetic counselors who are either directly employed or derive benefit from for-profit genomic testing companies to reveal those conflicts of interest. Consumers are now being marketed to seek guidance from professionals who have other than a fiduciary responsibility to them as patients. Disclosure of personal conflicts of interest is a key element in the provision of personalized medicine. Another emerging ethical issue bearing on the translation of genetics and genomics to personalized medicine is equity and access; there is the risk that these technologies will be available only to the affluent (Mardis 2010). This, in fact, was the experience in the clinical dissemination of preimplantation genetic diagnosis (Offit et al. 2006). Finally, as mentioned, there remains inconsistency in the ethical and legal definitions of "duty to warn" family members at potentially increased genetic-or genomic risk-of a disease or adverse outcome (Offit et al. 2004). In an era of over a half dozen "black box" FDA warnings, and over 60 labels with information regarding dosing or toxicity guidance based on genetic markers, it is known that risks for toxicity or altered metabolism follow Mendelian patterns. The unit of concern in genomics, as in genetics, is the risk to the family and not simply the individual.

\section{Concluding comments}

There is little debate that the extraordinary progress in genome science over the past decade, coupled with the declining cost of sequencing technologies, has brought the promise of personalized medicine closer than ever. However it still remains true, as Harold Varmus once said, that genomics is more a way to do science, not medicine (Wade 2010). Many in the field also share David Altshuler's skepticism about the promise of personalized medicine when it comes to common, complex diseases (Dougherty 2010). While it is true that the Human Genome Project has not yet directly affected the health care of most individuals, there have been dramatic examples of genetically targeted treatment and prevention, notably in the field of oncology (Collins 2010; Macconaill and Garraway 2010; Green and Guyer 2011). The past decade of translation of genetics to 
personalized medicine provides a roadmap to inform the incorporation of genomics into clinical practice during the decade ahead. For common variants, the paradox remains that that personalized medicine now requires populationsized experiments to explore common polygenes, environmental factors, and clinical endpoints (Orr and Chanock 2008). For rare disease predisposition syndromes and individual cancer genomes, the progress of sequencing technologies has made personalized genomics a reality (Meyerson et al. 2010). The computational and counseling challenges resulting from the emerging deluge of next generation sequencing data constitutes a barrier that will need to be surmounted to translate genomics research to practice, and to emerge from what Elaine Mardis has called the era of the $\$ 1,000$ genome and the $\$ 100,000$ analysis (Mardis 2010). Throughout this process, more clinical research in the validation (T2) and cost effectiveness (T4) end of the spectrum will be required to produce the evidentiary database to inform the practice of personalized medicine (Khoury et al. 2007). Commercial genomic testing labs, as well as genomics-based pharmaceutical companies will require this evidentiary foundation to obtain reimbursement for medical services. During this period of transition from investigation to practice, efforts will be needed to protect consumers against potential harms of premature translation of research findings, while encouraging innovative and cost effective application of those genomic discoveries that improve personalized medical care.

Acknowledgments $K$. Offit is a member of the Evaluation of Genomic Applications in Practice and Prevention (EGAPP) Working Group, an independent advisory group to the US Center for Disease Control, and currently chairs a working group considering issues of intellectual property in cancer genetics for the American Society of Clinical Oncology (ASCO). The views expressed in this article do not represent those of EGAPP, the CDC, ASCO, or the Memorial SloanKettering Cancer Center. Dr Offit has no investments in and does not sit on any paid advisory boards for commercial entities involved in personalized genomics. K. Offit is indebted to William Foulkes, M.B., Ph.D., and Mark E. Robson, M.D. for thoughtful discussions, and to Peter Thom, M.S., C.G.C., who assisted in the preparation of the Table and bibliographic research. This project was supported in part by the Robert and Kate Niehaus Clinical Cancer Genetics Initiative and The Sharon Levine Corzine Genetic Research Fund.

Open Access This article is distributed under the terms of the Creative Commons Attribution Noncommercial License which permits any noncommercial use, distribution, and reproduction in any medium, provided the original author(s) and source are credited.

\section{References}

Agency for Healthcare Research and Quality (2007) Testing for cytochrome P450 polymorphisms in adults with non-psychotic depression treated with selective serotonin reuptake inhibitors (SSRIs), structured abstract. January 2007, Rockville, MD. http://www.ahrq.gov/clinic/tp/cyp450tp.htm. Accessed 27 Jan 2011
American Society of Clinical Oncology, Offit K, Bertagnolli MM, Bombard AT, Come S, Eng C, Garber JE, Joffe S, Greene MH, Tucker MA, Gruber SB, Guillem J, Robson M, Halberg FE, Hampel H, Olopade OI, Rieger OT, Rodriguez-Bigas MA, Tomlinson G, Watson MS, Weber BL, Weitzel J, Wiesner GL (2003) American Society of Clinical Oncology policy statement update: genetic testing for cancer susceptibility. J Clin Oncol 21:2397-2406

American Society of Clinical Oncology, Offit K, Biesecker BB, Burt RW, Clayton EW, Garber JE, Kahn MJE, Lichter A, Lynch P, Watson MS, Weber BL, Wells SA (1996) Statement of the American Society of Clinical Oncology: genetic testing for cancer susceptibility. J Clin Oncol 14:1730-1736 (discussion 1737-1740, adopted on February 20, 1996)

American Society of Clinical Oncology, Robson ME, Storm CD, Weitzel J, Wollins DS, Offit K (2010) American Society of Clinical Oncology policy statement update: genetic and genomic testing for cancer susceptibility. J Clin Oncol 28:893-901

Antoniou AC, Beesley J, McGuffog L, Sinilnikova OM, Healey S, Neuhausen SL, Ding YC, Rebbeck TR, Weitzel JN, Lynch HT (2010) Common breast cancer susceptibility alleles and the risk of breast cancer for BRCA1 and BRCA2 mutation carriers: implications for risk prediction. Cancer Res 70:9742

Ashley EA, Butte AJ, Wheeler MT, Chen R, Klein TE, Dewey FE, Dudley JT, Ormond KE, Pavlovic A, Morgan AA, Pushkarev D, Neff NF, Hudgins L, Gong L, Hodges LM, Berlin DS, Thorn CF, Sangkuhl K, Hebert JM, Woon M, Sagreiya H, Whaley R, Knowles JW, Chou MF, Thakuria JV, Rosenbaum AM, Zaranek AW, Church GM, Greely HT, Quake SR, Altman RB (2010) Clinical assessment incorporating a personal genome. Lancet 375:1525-1535

Bennett KL, Mester J, Eng C (2010) Germline epigenetic regulation of KILLIN in Cowden and Cowden-like syndrome. JAMA 304:2724-2731

Bloss CS, Schork NJ, Topol EJ (2011) Effect of direct-to-consumer genomewide profiling to assess disease risk. $\mathrm{N}$ Engl $\mathrm{J}$ Med 364(6):524-534

Botstein D, Risch N (2003) Discovering genotypes underlying human phenotypes: past successes for Mendelian disease, future approaches for complex disease. Nat Genet 33(Suppl):228-237

Boulton SJ (2006) Cellular functions of the BRCA tumour-suppressor proteins. Biochem Soc Trans 34:633-645

Braithwaite D, Emery J, Walter F, Prevost AT, Sutton S (2004) Psychological impact of genetic counseling for familial cancer: a systematic review and meta-analysis. J Natl Cancer Inst 96:122-133

Bredenoord AL, Kroes HY, Cuppen E, Parker M, van Delden JJ (2011) Disclosure of individual genetic data to research participants: the debate reconsidered. Trends Genet 27(2):41-47

Carroll WL, Bhojwani D, Min DJ, Raetz E, Relling M, Davies S, Downing JR, Willman CL, Reed JC (2003) Pediatric acute lymphoblastic leukemia. Hematol Am Soc Hematol Educ Program 2003:102-131

Carvajal-Carmona LG (2010) Challenges in the identification and use of rare disease-associated predisposition variants. Curr Opin Genet Dev 20(3):277-281

Chamary JV, Parmley JL, Hurst LD (2006) Hearing silence: nonneutral evolution at synonymous sites in mammals. Nat Rev Genet 7:98-108

Collins F (2010) Has the revolution arrived? Nature 464:674-675

Colombo S, Rauch A, Rotger M, Fellay J, Martinez R, Fux C, Thurnheer C, Günthard HF, Goldstein DB, Furrer H, Telenti A, Swiss HIV Cohort Study (2008) The HCP5 singlenucleotide polymorphism: a simple screening tool for prediction of hypersensitivity reaction to abacavir. J Infect Dis 198:864-867 
Conti R, Veenstra DL, Armstrong K, Lesko LJ, Grosse SD (2010) Personalized medicine and genomics: challenges and opportunities in assessing effectiveness, cost-effectiveness, and future research priorities. Med Decis Mak 30:328-340

Davies K (2008) Keeping score of your genome. Bio IT World Nov 12, 2008. http://www.bio-itworld.com/issues/2008/nov-dec/ cover-story-keeping-score-of-your-sequence.html?terms=SNP edia\%3A+A+Wiki+for+Personal+Genomics. Accessed 1 June 2009

Domchek SM, Friebel TM, Singer CF, Evans DG, Lynch HT, Isaacs C, Garber JE, Neuhausen SL, Matloff E, Eeles R, Pichert G, Van t'veer L, Tung N, Weitzel JN, Couch FJ, Rubinstein WS, Ganz PA, Daly MB, Olopade OI, Tomlinson G, Schildkraut J, Blum JL, Rebbeck TR (2010) Association of risk-reducing surgery in BRCA1 or BRCA2 mutation carriers with cancer risk and mortality. JAMA 304:967-975

Dougherty E (2010) Twists of fate. Harv Med 83:12-19

Evaluation of Genomic Applications in Practice and Prevention (EGAPP) Working Group (2009a) Recommendations from the EGAPP Working Group: genetic testing strategies in newly diagnosed individuals with colorectal cancer aimed at reducing morbidity and mortality from Lynch syndrome in relatives. Genet Med 11:35-41

Evaluation of Genomic Applications in Practice and Prevention (EGAPP) Working Group (2009b) Recommendations from the EGAPP Working Group: can UGT1A1 genotyping reduce morbidity and mortality in patients with metastatic colorectal cancer treated with irinotecan? Genet Med 11(1):15-20

Evaluation of Genomic Applications in Practice and Prevention (EGAPP) Working Group (2010) Recommendations from the EGAPP Working Group: genomic profiling to assess cardiovascular risk to improve cardiovascular health. Genet Med $12: 839-843$

Evaluation of Genomic Applications in Practice and Prevention (EGAPP) Working Group (2011) Recommendations from the EGAPP Working Group: routine testing for Factor V Leiden (R506Q) and prothrombin (20210G $>$ A) mutations in adults with a history of idiopathic venous thromboembolism and their adult family members. Genet Med 13:67-76

Evans J, Khoury MJ (2007) Evidence based medicine meets genomic medicine. Genet Med 9:799-800

Fleming N (2008) Rival genetic tests leave buyers confused. Sunday Times Sept 7, 2008. http://www.timesonline.co.uk/tol/news/uk/ science/article4692891.ece. Accessed 1 Feb 2011

Galanello R, Origa R (2010) Beta-thalassemia. Orphanet J Rare Dis $5: 11$

Garber JE, Offit K (2005) Hereditary cancer predisposition syndromes. J Clin Oncol 23:276-292

Gaudet M, Kirchhoff T, Green T, Vijai J, Korn JM, Guiducci C, Segrè AV, McGee K, McGuffog L, Kartsonaki C, Morrison J, Healey S, Sinilnikova OM, Stoppa-Lyonnet D, Mazoyer S, GauthierVillars M, Sobol H, Longy M, Frenay M, GEMO Study Collaborators, Hogervorst FBL, Rookus M, Collée JM, Hoogerbrugge N, van Roozendaal KEP, The Hereditary Breast and Ovarian Cancer Research Group Netherlands, Piedmonte M, Rubinstein W, Nerenstone S, Van Le L, Blank SV, Caldes T, de la Hoya M, Nevanlinna $H$, Aittomäki K, Lazaro C, Blanco I, Arason A, Johannsson OT, Barkardottir RB, Devilee P, Olopade OI, Neuhausen SL, Wang X, Fredericksen ZS, Peterlongo P, Manoukian S, Barile M, Viel A, Radice P, Phelan CM, Narod S, Rennert G, Lejbkowicz F, Flugelman A, Andrulis I, Glendon G, Ozcelik H, Toland AE, Montagna M, D'Andrea E, Friedman E, Laitman Y, Borg A, Beattie M, Ramus SJ, Domchek SM, Nathanson KL, Rebbeck T, Spurdle A, Chen X, Holland H, kConFab, John EM, Hopper JL, Buys SS, Daly MB, Southey MC, Terry MB, Tung N, Hansen TVO, Nielsen FC, Greene M,
Mai PL, Osorio A, Durán M, Andres R, Benítez J, Weitzel JN, Garber J, Hamann U, Peock S, Cook M, Oliver C, Frost D, Platte R, Evans DG, Lalloo F, Eeles R, Izatt L, Walker L, Eason J, Barwell J, Godwin AK, Schmutzler RK, Wappenschmidt B, Engert S, Arnold N, Gadzicki D, Dean M, Gold B, Klein RJ, Couch FJ, Chenevix-Trench G, Easton DF, Daly MJ, Antoniou AC, Altshuler DM, Offit K (2010) Common genetic variants and modification of penetrance of BRCA2-associated breast cancer. PLoS Genet 6(10):e1001183

Green ED, Guyer MS (2011) Charting a course for genomic medicine from base pairs to bedside. Nature 470:204-213

Green RC, Roberts JS, Cupples LA, Relkin NR, Whitehouse PJ, Brown T, Eckert SL, Butson M, Sadovnick AD, Quaid KA, Chen C, Cook-Deegan R, Farrer LA, REVEAL Study Group (2009) Disclosure of APOE genotype for risk of Alzheimer's disease. N Engl J Med 361(3):245-254

Guttmacher AE, Collins FS (2002) Genomic medicine: a primer. N Engl J Med 347:1512-1520

Haddow JE, Palomaki GE (2004) A model process for the evaluating data on emerging genetic tests. In: Khoury MJ, Little J, Burke W (eds) Human genome epidemiology: scope and strategies. Oxford University Press, New York, pp 217-233

Hamburg MA, Collins FS (2010) The path to personalized medicine. N Engl J Med 363:301-304

Heshka JT, Palleschi C, Howley H, Wilson B, Wells PS (2008) A systematic review of perceived risks, psychological and behavioral impacts of genetic testing. Genet Med 10:19-32

Hitchins MP (2010) Inheritance of epigenetic aberrations (constitutional epimutations) in cancer susceptibility. Adv Genet 70:201-243

H.R. 5440 (2010) Genomics and personalized medicine act of 2010. http://www.opencongress.org/bill/111-h5440/text. Accessed 27 Jan 2011

Katz DA, Bhathena A (2009) Overview of pharmacogenetics. Curr Protoc Hum Genet Chap 9:Unit 9.19

Keller MA, Gordon ES, Stack CB, Gharani N, Sill CJ, Schmidlen TJ, Joseph M, Pallies J, Gerry NP, Christman MF (2010) Coriell Personalized Medicine Collaborative ${ }^{\circledR}$ : a prospective study of the utility of personalized medicine. Pers Med 7:301-317

Khoury MJ (2003) Genetics and genomics in practice: the continuum from genetic disease to genetic information in health and disease. Genet Med 5:261-268

Khoury MJ, Gwinn M, Yoon PW, Dowling N, Moore CA, Bradley L (2007) The continuum of translation research in genomic medicine: how can we accelerate the appropriate integration of human genome discoveries into health care and disease prevention? Genet Med 9:665-674

Khoury MJ, McBride CM, Schully SD, Ioannidis JP, Feero WG, Janssens AC, Gwinn M, Simons-Morton DG, Bernhardt JM, Cargill M, Chanock SJ, Church GM, Coates RJ, Collins FS, Croyle RT, Davis BR, Downing GJ, Duross A, Friedman S, Gail MH, Ginsburg GS, Green RC, Greene MH, Greenland P, Gulcher JR, Hsu A, Hudson KL, Kardia SL, Kimmel PL, Lauer MS, Miller AM, Offit K, Ransohoff DF, Roberts JS, Rasooly RS, Stefansson K, Terry SF, Teutsch SM, Trepanier A, Wanke KL, Witte JS, Xu J, Centers for Disease Control and Prevention (2009) The Scientific Foundation for personal genomics: recommendations from a National Institutes of Health-Centers for Disease Control and Prevention multidisciplinary workshop. Genet Med 11:559-567

Kim C, Paik S (2010) Gene-expression-based prognostic assays for breast cancer. Nat Rev Clin Oncol 7:340-347

Klein TE, Altman RB, Eriksson N, Gage BF, Kimmel SE, Lee MT, Limdi NA, Page D, Roden DM, Wagner MJ, Caldwell MD, Johnson JA (2009) Estimation of the warfarin dose with clinical and pharmacogenetic data. N Engl J Med 360:753-764 
Lammens CR, Aaronson NK, Wagner A, Sijmons RH, Ausems MG, Vriends AH, Ruijs MW, van Os TA, Spruijt L, Gómez García EB, Kluijt I, Nagtegaal T, Verhoef S, Bleiker EM (2010) Genetic testing in Li-Fraumeni syndrome: uptake and psychosocial consequences. J Clin Oncol 28:3008-3014

Law AJ, Lipska BK, Weickert CS, Hyde TM, Straub RE, Hashimoto R, Harrison PJ, Kleinman JE, Weinberger DR (2006) Neuregulin 1 transcripts are differentially expressed in schizophrenia and regulated by $5^{\prime}$ SNPs associated with the disease. Proc Natl Acad Sci USA 103:6747-6752

Lehnart SE, Ackerman MJ, Benson DW, Brugada R, Clancy CE, Donahue JK, George AL, Grant AO, Groft SC, January CT, Lathrop DA, Lederer WJ, Makielski JC, Mohler PJ, Moss A, Nerbonne JM, Olson TM, Przywara DA, Towbin JA, Wang LH, Marks AR (2007) Inherited arrhythmias: a National Heart, Lung, and Blood Institute and Office of Rare Diseases workshop consensus report about the diagnosis, phenotyping, molecular mechanisms, and therapeutic approaches for primary cardiomyopathies of gene mutations affecting ion channel function. Circulation 116:2325-2345

Leyland-Jones B, Regan MM, Bouzyk M, Kammler R, Tang W, Pagani O, Malbach R, Dell'Orto P, Thürlimann B, Price KN, Viale G (2010) Outcome according to CYP2D6 genotype among postmenopausal women with endocrine-responsive early invasive breast cancer randomized in the BIG 1-98 trial. In: Program and abstracts of the 33rd annual San Antonio breast cancer symposium, San Antonio, Texas, 8-12 December 2010, Abstract S1-S8

Macconaill LE, Garraway LA (2010) Clinical implications of the cancer genome. J Clin Oncol 28(35):5219-5228

Maher B (2008) Personal genomes: the case of the missing heritability. Nature 456:18-21

Malik NN, Khan Y (2010) Personalized medicine: potential impact on the biopharmaceutical industry. Drug Discov Today 15(22):881883

Manolio TA (2010) Genomewide association studies and assessment of the risk of disease. New Engl J Med 363:166-176

Mardis ER (2010) The $\$ 1000$ genome, the $\$ 100,000$ analysis? Genome Med 2:84

Marshall E (2011) Waiting for the revolution. Science 331:526-529

McDermott U, Downing JR, Stratton MR (2011) Genomics and the continuum of cancer care. N Engl J Med 364:340-350

Meckley LM, Gudgeon JM, Anderson JL, Williams MS, Veenstra DL (2010) A policy model to evaluate the benefits, risks and costs of warfarin pharmacogenomic testing. Pharmacoeconomics 28:61-74

Meyerson M, Gabriel S, Getz G (2010) Advances in understanding cancer genomes through second-generation sequencing. Nat Rev Genet 11:685-696

Napolitano C, Priori SG, Schwartz PJ, Bloise R, Ronchetti E, Nastoli J, Bottelli G, Cerrone M, Leonardi S (2005) Genetic testing in the long QT syndrome: development and validation of an efficient approach to genotyping in clinical practice. JAMA 294:2975-2980

National Cancer Institute, USNIH (2011) http://www.cancer.gov/ dictionary/?CdrID=561717. Accessed 27 Jan 2011

National Human Genome Research Institute, NIH (2010) Frequently asked questions about genetic and genomic science. http://www. genome.gov/19016904. Accessed 27 Jan 2011

Ng PC, Murray SS, Levy S, Venter JC (2009) An agenda for personalized medicine. Nature 461(7265):724-726

Nicol AF, Nuovo GJ, Dillner J (2010) A summary of the 25th international papillomavirus conference 2009: vaccines, screening, epidemiology and therapeutics. J Clin Virol 47:208-215

Offit K (1998) Clinical cancer genetics. Wiley, New York

Offit K (2008) Genomic profiles for disease risk: predictive or premature? JAMA 299:1353-1355
Offit K (2009) Breast cancer single-nucleotide polymorphisms: statistical significance and clinical utility. J Natl Cancer Inst 101:973-975

Offit K, Groeger E, Turner S, Wadsworth EA, Weiser MA (2004) The "duty to warn" a patient's family members about hereditary disease risks. JAMA 292:1469-1473

Offit K, Sagi M, Hurley K (2006) Preimplantation genetic diagnosis for cancer syndromes: a new challenge for preventive medicine. JAMA 296(22):2727-2730

Ormond KE, Wheeler MT, Hudgins L, Klein TE, Butte AJ, Altman RB, Ashley EA, Greely HT (2010) Challenges in the clinical application of whole-genome sequencing. Lancet 375(9727): 1749-1751

Orr N, Chanock S (2008) Common genetic variation and human disease. Adv Genet 62:1-32

Peres J (1999) Genetic testing can save lives-but errors leave scars. Chicago Tribune, September 26, 1999. http://articles. chicagotribune.com/1999-09-26/news/9909260331_1_oncormedovarian-cancer-prophylactic-mastectomies. Accessed 1 Feb 2011

Pham TN, Coffin CS, Michalak TI (2010) Occult hepatitis C virus infection: what does it mean? Liver Int 30:502-511

Pomerantz MM, Ahmadiyeh N, Jia L, Herman P, Verzi MP, Doddapaneni H, Beckwith CA, Chan JA, Hills A, Davis M, Yao K, Kehoe SM, Lenz HJ, Haiman CA, Yan C, Henderson BE, Frenkel B, Barretina J, Bass A, Tabernero J, Baselga J, Regan MM, Manak JR, Shivdasani R, Coetzee GA, Freedman ML (2009) The 8q24 cancer risk variant rs6983267 shows longrange interaction with MYC in colorectal cancer. Nat Genet $41: 882-884$

Poort SR, Rosendaal FR, Reitsma PH, Bertina RM (1996) A common genetic variation in the $3^{\prime}$-untranslated region of the prothrombin gene is associated with elevated plasma prothrombin levels and an increase in venous thrombosis. Blood 88:3698-3703

Prior TW, Professional Practice and Guidelines Committee (2008) Carrier screening for spinal muscular atrophy. Genet Med $10: 840-842$

Provine WB (2001) The origins of theoretical population genetics, 2nd edn. The University of Chicago Press, Chicago

Rae JM, Drury S, Hayes DF, Stearns V, Thibert JN, Haynes BP, Salter J, Pineda S, Cuzick J, Dowsett M (2010) Lack of correlation between gene variants in tamoxifen metabolizing enzymes with primary endpoints in the ATAC trial. In: Program and abstracts of the 33rd annual San Antonio breast cancer symposium, San Antonio, Texas, 8-12 December 2010, Abstract S1-S7

Robson M, Offit K (2007) Clinical practice. Management of an inherited predisposition to breast cancer. $\mathrm{N}$ Engl $\mathrm{J}$ Med 357:154-162

Rosenwald A, Wright G, Chan WC et al (2002) The use of molecular profiling to predict survival after chemotherapy for diffuse largeB-cell lymphoma. N Engl J Med 346:1937-1947

Schadt EE, Friend SH, Shaywitz DA (2009) A network view of disease and compound screening. Nat Rev Drug Discov 8:286-295

Schork NJ, Murray SS, Frazer KA, Topol EJ (2009) Common vs rare allele hypothesis for complex diseases. Curr Opin Genet Dev 19:212-219

Sebat J, Lakshmi B, Malhotra D, Troge J, Lese-Martin C, Walsh T, Yamrom B, Yoon S, Krasnitz A, Kendall J, Leotta A, Pai D, Zhang R, Lee YH, Hicks J, Spence SJ, Lee AT, Puura K, Lehtimäki T, Ledbetter D, Gregersen PK, Bregman J, Sutcliffe JS, Jobanputra V, Chung W, Warburton D, King MC, Skuse D, Geschwind DH, Gilliam TC, Ye K, Wigler M (2007) Strong association of de novo copy number mutations with autism. Science 316:445-449

Sherman S, Pletcher BA, Driscoll DA (2005) Fragile X syndrome: diagnostic and carrier testing. Genet Med 7:584 
Shields PG, Harris CC (2000) Cancer risk and low-penetrance susceptibility genes in gene-environment interactions. J Clin Oncol 18:2309-2315

Shuldiner AR, O'Connell JR, Bliden KP, Gandhi A, Ryan K, Horenstein RB, Damcott CM, Pakyz R, Tantry US, Gibson Q, Pollin TI, Post W, Parsa A, Mitchell BD, Faraday N, Herzog W, Gurbel PA (2009) Association of cytochrome P450 2C19 genotype with the antiplatelet effect and clinical efficacy of clopidogrel therapy. JAMA 302:849-857

Sorlie T, Perou CM, Tibshirani R et al (2001) Gene expression patterns of breast carcinomas distinguish tumor subclasses with clinical implications. Proc Natl Acad Sci USA 98: 10869-10874

Spearman AD, Sweet K, Zhou XP, McLennan J, Couch FJ, Toland AE (2008) Clinically applicable models to characterize BRCA1 and BRCA2 variants of uncertain significance. J Clin Oncol 26:5393-5400

Spiegel Online International (2010) SPIEGEL interview with Craig venter 'we have learned nothing from the genome'. http://www. spiegel.de/international/world/0,1518,709174,00.html. Accessed 27 Jan 2011

Stadler ZK, Vijai J, Thom P, Kirchhoff T, Hansen NA, Kauff ND, Robson M, Offit K (2010) Genome-wide association studies of cancer predisposition. Hematol Oncol Clin N Am 24:973-996

Steele FR (2009) Personalized medicine: something old, something new. Pers Med 6:1-5

Teutsch SM, Bradley LA, Palomaki GE, Haddow JE, Piper M, Calonge N, Dotson WD, Douglas MP, Berg ZO, EGAPP Working Group (2009) The Evaluation of Genomic Applications in Practice and Prevention (EGAPP) Initiative: methods of the EGAPP Working Group. Genet Med 11:3-14

The Thousand Genomes Project Consortium (2010) A map of human genome variation from population-scale sequencing. Nature 467:1061-1073

Tsalik EL, Jones D, Nicholson B, Waring L, Liesenfeld O, Park LP, Glickman SW, Caram LB, Langley RJ, van Velkinburgh JC,
Cairns CB, Rivers EP, Otero RM, Kingsmore SF, Lalani T, Fowler VG, Woods CW (2010) Multiplex PCR to diagnose bloodstream infections in patients admitted from the emergency department with sepsis. J Clin Microbiol 48:26-33

U.S. Food and Drug Administration (2011) Table of pharmacogenomic biomarkers in drug labels. http://www.fda.gov/Drugs/ ScienceResearch/ResearchAreas/Pharmacogenetics/ucm083378. htm. Accessed 31 Jan 2011

Vissers LE, de Ligt J, Gilissen C, Janssen I, Steehouwer M, de Vries P, van Lier B, Arts P, Wieskamp N, del Rosario M, van Bon BW, Hoischen A, de Vries BB, Brunner HG, Veltman JA (2010) A de novo paradigm for mental retardation. Nat Genet 42:1109-1112

Vorhaus D (2010) "From gulf oil to snake oil": congress takes aim at DTC genetic testing. Genomic Law Report (Website). http://www. genomicslawreport.com/index.php/2010/07/22/from-gulf-oil-tosnake-oil-congress-takes-aim-at-dtc-genetic-testing/. Accessed 27 Jan 2011

Wade N (2010) A decade later, genetic map yields few new cures. The New York Times, p A1

Watson J (2009) Living with my personal genome. Pers Med 6:697

Weinberg R (2010) Point: hypotheses first. Nature 464:678

Wellcome Trust Case Control Consortium (2007) Genome-wide association study of 14,000 cases of seven common diseases and 3,000 shared controls. Nature 447:661-678

Wiggins S, Whyte P, Huggins M, Adam S, Theilmann J, Bloch M, Sheps SB, Schechter MT, Hayden MR (1992) The psychological consequences of predictive testing for Huntington's disease. Canadian Collaborative Study of Predictive Testing. N Engl J Med 327:1401-1405

Wilensky GR (2006) Developing a center for comparative effectiveness information. Health Aff (Millwood) 25:w572-w585

Zilliacus EM, Meiser B, Lobb EA, Kirk J, Warwick L, Tucker K (2010) Women's experience of telehealth cancer genetic counseling. J Genet Couns 19(5):463-472 